\title{
VARIASI MODEL SILOGISME UNTUK PENGAMBILAN KESIMPULAN DALAM PEMBELAJARAN MATEMATIKA DI SEKOLAH DASAR
}

\author{
Elly's Mersina Mursidik*
}

\begin{abstract}
Logical argumentations are required in communication and interactions between students and teachers. Classroom activities lead continuous or discontinuous communication and interactions. This is due to the questions by the teacher to the students contains logical truth. The value of the logical truth makes the teaching and learning activities run as they are planned. Questions for the students should be tautologies rather than those contradictory.
\end{abstract}

Key words: Syllogism, Tautology, Conclusion, Interaction

\begin{abstract}
Abstrak
Argumentasi logis perlu digunakan dalam pembelajaran untuk melakukan komunikasi dan interaksi antara guru dan siswa. Kegiatan di kelas mengakibatkan komunikasi dan interaksi yang berkesinambungan atau tidak berkesinambungan. Hal ini disebabkan oleh pernyataan yang dilontarkan seorang guru kepada siswa mempunyai nilai kebenaran logis. Nilai kebenaran logis tersebut yang menjadikan kegiatan pembelajaran dapat dapat berlangsung dengan program yang direncakan. Penyampaian kepada siswa tentunya harus menghindari dari pernyataan kontradiksi dan diusahakan merupakan pernyataan tautology.
\end{abstract}

Kata kunci: Silogisme, Tautology, Kesimpulan dan Interaksi

* Elly's Mersina Mursidik adalah Dosen PGSD IKIP PGRI Madiun

\section{A. Pendahuluan}

Manusia pada hakikatnya berkomunikasi dengan orang lain pastilah muncul kata-kata yang kemudian dirangkai menjadi kalimat. Kalimat tersebut ada yang merupakan kalimat tanya, berita, aktif ataupun pasif dan sebagainya. Semua kalimat tersebut muncul secara sadar disampaikan oleh orang dalam berkomunikasi untuk memperlancar interaksi dengan orang lain. Interaksi yang dilakukan setiap individu dapat terjadi dalam keadaan privasi ataupun berkelompok. Interaksi privasi terjadi ketika kita berkomunikasi dengan satu individu secara langsung baik secara tatap muka ataupun menggunakan alat komunikasi. Sedangkan interaksi berkelompok terjadi pada saat kita berkomunikasi dengan kelompok individu secara langsung atau tidak langsung. 
Hal tersebut sering dilakukan dalam lingkungan keluarga, masyarakat, sekolah, instansi ataupun kelompok-kelompok yang lain.

Dalam pembelajaran matematika argumen sangat diperlukan sebagai cara untuk mengambil sebuah kesimpulan. Argumentasi dalam pembahasan ini adalah penegasan bahwa dari beberapa pernyataan tunggal atau majemuk yang diketahui (disebut premis), melalui langkah-langkah logis dapat diturunkan suatu pernyataan tunggal atau majemuk yang benar (disebut kesimpulan atau konklusi). Suatu argumentasi dikatakan berlaku atau sah jika dan hanya jika konjungsi dari premis-premisnya berimplikasi konklusi merupakan Tautologi (Sukirman, 2001).

Pada pembelajaran di sekolah penjelasan-penjelasan awal secara berurutan sesuai dengan yang akan simpulkan maka pembelajaran tersebut secara logis benar, akan tetapi bila penjelasan-penjelasan awal tidak sesuai dengan kesimpulan pada pembelajaran maka pembelajaran tersebut secara logis tidak benar. Pembelajaran matematika sering menggunakan argument logis untuk memperoleh sebuah generalisasi kesimpulan. Theorema, dalil, postulat dan rumus merupakan sebuah kesimpulan yang diperoleh dari keterkaitan aksioma-akioma.

Beberapa cara memberikan pernyataan atau jawaban dengan menggunakan modus ponens, modus tollend, silogisme atau modus yang lain. Modus ponens sah menyatakan "Jika p maka q (premis 1) dan ternyata terjadi p (premis 2) maka dapat disimpulkan q (konklusi)" dan tidak sah dinyatakan "Jika p maka q (premis 1) dan ternyata terjadi q (premis 2) maka dapat disimpulkan $p$ (konklusi)". Modus tollend sah menyatakan "Jika p maka q (premis 1) dan ternyata terjadi tidak q (premis 2)maka dapat disimpulkan tidak p (konklusi)" dan tidak sah dinyatakan "Jika p maka q (premis 1) dan ternyata terjadi tidak p (premis 2) maka dapat disimpulkan tidak q (konklusi)". Silogisme merupakan cara untuk menyimpulkan yang didasari dari premis-premis yang merupakan pernyataan majemuk berimplikasi. Jelasnya dinyatakan " jika terjadi p maka terjadi q (premis 1)dan apabila terjadi q maka terjadi $r$ (premis 2) sehingga dapat disimpulkan jika terjadi p maka terjadilah $r$ (konklusi)". Silogisme merupakan salah satu cara yang tepat untuk menyimpulkan sesuatu yang berdasarkan urutan waktu (Sukirman, 2001).

Dalam perjalanannya untuk memperluas model modus silogisme akan dibahas dalam pembahasan, sehingga dapat diperoleh beberapa kesimpulan yang diperoleh melalui silogisme. Secara umum teknik pengambilan keputusan yaitu menggabungkan beberapa premis kemudian diimplikasikan dengan kesimpulan, rangkaian penyataan tersebut merupakan pernyataaan tautologi (Sukirman, 2001).

(((Primis 1 dan Pemis 2) dan premis 3) dan ...premis $n$ ) maka diperoleh kesimpulan

$$
\left(\left(\left(P_{1} \wedge P_{2}\right) \wedge P_{3}\right) \wedge \ldots P_{n}\right) \Rightarrow K
$$

\section{B. Pembahasan}

Mengerti dan memahami pernyataan merupakan langkah pertama dalam mengambil kesimpulan, maka sebagai awal pembahasan untuk memahami modelmodel silogisme perlu diperhatikan beberapa hal sebagai berikut: 


\section{Pernyataan Majemuk}

Pernyataan merupakan sebuah kalimat yang memiliki nilai kebenaran logis benar atau salah akan tetapi tidak keduanya. Kebenaran sebuat pernyataan ditinjau dari content isi makmanya. Pernyataan tersebut merupakan pernyataan tunggal yang menjadi dasar kebenaran pernyataan majemuk (Setiaji, 2001). Pernyataan majemuk meliputi konjungsi, disjungsi, implikasi, biimplikasi atau implikasi dua arah. Konjungsi merupakan pernyataan majemuk yang dibentuk dari gabungan beberapa penyataan tunggal dengan kata hubungnya "dan". Selain itu konjungsi mempunyai nilai kebenaran apa bila semua pernyataan tunggalnya bernilai benar. Beberapa pernyataan tunggal yang digabung dengan kata hubung "atau" disebut dengan pernyaan disjungsi dengan nilai kebenarannya akan bernilai salah apabila semua pernyataan tunggal bernilai salah (Setiaji, 2001).

Implikasi merupakan pernyataan majemuk yang terbentuk dengan merangkai pernyataan tunggal dengan rangkaian "jika terjadi sesuatu (alasan) maka terjadi sesuatu (kesimpulan)" dalan konteks ini sesuatu dapat diartikan bebagai hal sesuai dengan semesta pembicaraan. Kebenaran logisnya dapat ditinjau dari kesimpulan yang benar akan tetapi apabila alasan dan kesimpulannya salah, impilkasi tersebut benar (Munir, 2008).

Biimplikasi merupakan konjungsi implikasi yang saling konvers. Dengan pernyataan "Jika terjadi $p$ maka disimpulkan $q$ dan jika terjadi q maka disimpulkan p" atau " $p$ terjadi jika dan hanya jika q". Adapun nilai kebenaranya ditentukan dari peryataan tunggalnya, bernilai benar bila semuanya benar atau semua salah (Munir, 2008).

\section{Impilkasi, Konvers, Invers dan Kontraposisi}

Implikasi telah dijelaskan bahwa pernyataan majemuk yang terdiri dari pernyataan tunggal sebagai alasan dan pernyataan tunggal sebagai kesimpulannya. Dalam hal ini apabila pernyaatan tunggal yang menjadi kesimpulan diubah menjadi alasan dan pernyataan tunggal yang menjadi alasan diubah menjadi kesimpulan disebut konvers impilkasi. Sedangkan pernyataan implikasi dengan pernyataan tunggal sebagai alasan dan pernyataan tunggal sebagai kesimpulan diingkari disebut dengan invers implikasi. Dalam kontraposisi implikasi pernyataan tunggal sebagai alasan diubah menjadi kesimpulan dan pernyataan tunggal sebagai kesimpulan diubah menjadi alasan serta kemudian keduanya diingkari (Silaban, 1985).

Perlu juga diketahui bahwa kebenaran implikasi sama dengan kebenaran kontraposisi sehingga dapat menyatakan implikasi atau kontraposisi. Sedangkan konvers implikasi dan invers implikasi juga memiliki nilai kebenaran yang sama dikarenakan saling kontraposisi sehingga dapat menyatakan dalam bentuk invers atau konvers.

\section{Tautology dan Kontradiksi}

Pernyataan mempunyai nilai benar atau salah maka pernyataan majemuk juga memiliki nilai benar dan salah. Tautology merupakan rangkaian penyataan majemuk yang memiliki nilai logis selalu benar walaupun ada beberapa pernyataan tunggal bernilai salah. Sedangkan kontradiksi merupakan lawan dari 
tautology yaitu rangkaian pernyataan majemuk yang memiliki nilai logis selalu salah walaupun ada beberapa pernyataan tunggal bernilai benar (Silaban, 1985). Dalam praktiknya diusakan kita selalu memberikan pernyataan benar dalam rangkaian pernyataan majemuk sehingga dapat dipercaya oleh orang lain. Apabila kita memberikan jawaban dan kesimpulan dengan pernyataan yang kontradiksi maka dapat mengakibatkan hilangnya kepercayaan yang diberikan kepada kita. Sebagai contoh sederhan tautology adalah modus ponens, modus tollens dan silogisme. Untuk membuktikan kebenarannya perhatikan tabel berikut.

Table 1 Modus Ponens (jika terjadi p maka terjadi q dan ternyata terjadi p maka dapat disimpulkan terjadi q)

\begin{tabular}{|c|c|c|c|c|c|c|}
\hline $\mathbf{p}$ & $\mathbf{q}$ & $\mathbf{p} \Rightarrow \mathbf{q}$ & dan & $\mathbf{p}$ & maka & $\mathbf{q}$ \\
\hline B & B & B & B & B & B & B \\
\hline B & S & S & S & B & B & S \\
\hline S & B & B & S & S & B & B \\
\hline S & S & B & $S$ & S & B & S \\
\hline
\end{tabular}

Sumber: Lipschutz dan Silaban (1985)

Tabel 2 Modus Tollend (jika terjadi p maka terjadi q dan ternyata terjadi bukan $p$ maka dapat disimpulkan terjadi bukan q)

\begin{tabular}{|c|c|c|c|c|c|c|}
\hline $\mathbf{p}$ & $\mathbf{q}$ & $\mathbf{p} \Rightarrow \mathbf{q}$ & dan & $\sim \mathbf{q}$ & maka & $\sim \mathbf{p}$ \\
\hline B & B & B & $S$ & S & B & B \\
\hline B & S & S & $S$ & B & B & S \\
\hline S & B & B & $S$ & S & B & B \\
\hline S & S & B & $S$ & B & B & S \\
\hline
\end{tabular}

Sumber: Lipschutz dan Silaban (1985)

Table 3 Silogisme (Jika terjadi $p$ maka terjadi q dan jika terjadi q maka terjadi $r$ sehingga dapat disimpulkan jika terjadi p maka terjadi $r$ )

\begin{tabular}{|c|c|c|c|c|c|c|c|}
\hline $\mathbf{p}$ & $\mathbf{q}$ & $\mathbf{r}$ & $\mathbf{p} \Rightarrow \mathbf{q}$ & dan & $\mathbf{q} \Rightarrow \mathbf{r}$ & maka & $\mathbf{p} \Rightarrow \mathbf{r}$ \\
\hline B & B & B & B & B & B & B & B \\
\hline B & B & S & B & S & S & B & S \\
\hline B & S & B & S & S & B & B & B \\
\hline B & S & S & S & S & B & B & S \\
\hline S & B & B & B & B & B & B & B \\
\hline
\end{tabular}




\begin{tabular}{|c|c|c|c|c|c|c|c|}
\hline $\mathbf{p}$ & $\mathbf{q}$ & $\mathbf{r}$ & $\mathbf{p} \Rightarrow \mathbf{q}$ & dan & $\mathbf{q} \Rightarrow \mathbf{r}$ & maka & $\mathbf{p} \Rightarrow \mathbf{r}$ \\
\hline $\mathbf{S}$ & $\mathbf{B}$ & $\mathbf{S}$ & $\mathbf{B}$ & $\mathbf{S}$ & $\mathbf{S}$ & $\mathbf{B}$ & $\mathbf{B}$ \\
\hline $\mathbf{S}$ & $\mathbf{S}$ & $\mathbf{B}$ & $\mathbf{B}$ & $\boldsymbol{B}$ & $\mathbf{B}$ & $\mathbf{B}$ & $\mathbf{B}$ \\
\hline $\mathbf{S}$ & $\mathbf{S}$ & $\mathbf{S}$ & $\mathbf{B}$ & $\boldsymbol{B}$ & $\mathbf{B}$ & $\mathbf{B}$ & $\mathbf{B}$ \\
\hline
\end{tabular}

Sumber: Lipschutz dan Silaban (1985)

Dengan memperhatikan tabel di atas maka perlu sebuah tautology untuk mengabil kesimpulan dengan benar dan sah dalam interaksi dalam kelompok individu.

\section{Model Silogisme}

Berdasarkan silogisme pada pembahasan awal dapat dikembangkan model-model silogisme baru dengan menggunakan pemikiran-pemikiran implikasi, konvers, invers dan kontraposisi. Kebenaran impilikasi ekuivalen logis dengan kontraposisi dan kebenaran konvers implikasi ekuivalen logis dengan invers implikasi. Selain itu juga perlu dipertahankan kebenaran logisnya yang merupakan sebuah tautology sehingga dapat digunakan sebagai cara mengambil kesimpulan yang benar. Adapun model-model silogisme dan bukti kebenaranya seperti diilustrasikan pada Tabel 4.

Tabel 4 Model Silogisme dan Bukti Kebenarannya

\begin{tabular}{|c|c|c|c|c|c|c|c|c|c|l|}
\hline 1 & $p$ & $q$ & $r$ & $p \Rightarrow q$ & dan & $q \Rightarrow r$ & maka & $\sim r \Rightarrow \sim p$ & & \\
\hline 2 & $p$ & $q$ & $r$ & $p \Rightarrow q$ & dan & $q \Rightarrow r$ & maka & $\sim r \Rightarrow \sim p$ & & \\
\hline 3 & $p$ & $q$ & $r$ & $p \Rightarrow q$ & dan & $q \Rightarrow r$ & maka & $p \Rightarrow r$ & Atau /dan & $\sim r \Rightarrow \sim p$ \\
\hline 4 & $p$ & $q$ & $r$ & $p \Rightarrow q$ & dan & $\sim r \Rightarrow \sim q$ & maka & $p \Rightarrow r$ & & \\
\hline 5 & $p$ & $q$ & $r$ & $p \Rightarrow q$ & dan & $\sim r \Rightarrow \sim q$ & maka & $\sim r \Rightarrow \sim p$ & & \\
\hline 6 & $p$ & $q$ & $r$ & $p \Rightarrow q$ & dan & $\sim r \Rightarrow \sim q$ & maka & $p \Rightarrow r$ & Atau /dan & $\sim r \Rightarrow \sim p$ \\
\hline 7 & $p$ & $q$ & $r$ & $\sim q \Rightarrow \sim p$ & dan & $q \Rightarrow r$ & maka & $p \Rightarrow r$ & & \\
\hline 8 & $p$ & $q$ & $r$ & $\sim q \Rightarrow \sim p$ & dan & $q \Rightarrow p$ & maka & $\sim r \Rightarrow \sim p$ & & \\
\hline 9 & $p$ & $q$ & $r$ & $\sim q \Rightarrow \sim p$ & dan & $q \Rightarrow r$ & maka & $p \Rightarrow r$ & Atau /dan & $\sim r \Rightarrow \sim p$ \\
\hline 10 & $p$ & $q$ & $r$ & $\sim q \Rightarrow \sim p$ & dan & $\sim r \Rightarrow \sim q$ & maka & $p \Rightarrow r$ & & \\
\hline 11 & $p$ & $q$ & $r$ & $\sim q \Rightarrow \sim p$ & dan & $\sim r \Rightarrow \sim q$ & maka & $\sim r \Rightarrow \sim p$ & & \\
\hline 12 & $p$ & $q$ & $r$ & $\sim q \Rightarrow \sim p$ & dan & $\sim r \Rightarrow \sim q$ & maka & $p \Rightarrow r$ & Atau /dan & $\sim r \Rightarrow \sim p$ \\
\hline
\end{tabular}


Berdasarkan Tabel 4 dapat dijelaskan:

a. Silogisme model I

Jika terjadi $\mathrm{p}$ maka terjadi q dan jika terjadi q maka terjadi $\mathrm{r}$ sehingga dapat disimpulkan jika tidak terjadi $r$ maka tidak terjadi $\mathrm{p}$.

b. Silogisme model II

Jika terjadi $\mathrm{p}$ maka terjadi q dan jika terjadi q maka terjadi $\mathrm{r}$ sehingga dapat disimpulkan jika tidak terjadi $r$ maka tidak terjadi $\mathrm{p}$.

c. Silogisme model III

Jika terjadi $\mathrm{p}$ maka terjadi $\mathrm{q}$ dan jika terjadi q maka terjadi $\mathrm{r}$ sehingga dapat disimpulkan jika terjadi $\mathrm{p}$ maka terjadi $\mathrm{r}$ atau jika tidak terjadi $\mathrm{r}$ maka tidak terjadi $\mathrm{p}$.

d. Silogisme model IV

Jika terjadi $\mathrm{p}$ maka terjadi $\mathrm{q}$ dan jika tidak terjadi $\mathrm{r}$ maka tidak terjadi $\mathrm{q}$ sehingga dapat disimpulkan jika terjadi $\mathrm{p}$ maka terjadi $\mathrm{r}$

e. Silogisme model V

Jika terjadi $\mathrm{p}$ maka terjadi $\mathrm{q}$ dan jika tidak terjadi $\mathrm{r}$ maka tidak terjadi $\mathrm{q}$ sehingga dapat disimpulkan jika tidak terjadi $\mathrm{r}$ maka tidak terjadi $\mathrm{p}$

f. Silogisme model VI

Jika terjadi $\mathrm{p}$ maka terjadi $\mathrm{q}$ dan jika tidak terjadi $\mathrm{r}$ maka tidak terjadi $\mathrm{q}$ sehingga dapat disimpulkan jika terjadi $\mathrm{p}$ maka terjadi $\mathrm{r}$ atau jika tidak terjadi $\mathrm{r}$ maka tidak terjadi $\mathrm{p}$.

g. Silogisme model VII

Jika tidak terjadi q maka tidak terjadi $\mathrm{p}$ dan jika terjadi $\mathrm{q}$ maka terjadi $\mathrm{r}$ sehingga dapat disimpulkan jika terjadi $\mathrm{p}$ maka terjadi $\mathrm{r}$.

h. Silogisme model VIII

Jika tidak terjadi q maka tidak terjadi $\mathrm{p}$ dan jika terjadi $\mathrm{q}$ maka terjadi $\mathrm{r}$ sehingga dapat disimpulkan jika tidak terjadi $r$ maka tidak terjadi $\mathrm{p}$.

i. Silogisme model IX

Jika tidak terjadi $\mathrm{p}$ maka tidak terjadi $\mathrm{q}$ dan jika terjadi $\mathrm{q}$ maka terjadi $\mathrm{r}$ sehingga dapat disimpulkan jika terjadi $\mathrm{p}$ maka terjadi $\mathrm{r}$ atau jika tidak terjadi $\mathrm{r}$ maka tidak terjadi $\mathrm{p}$.

j. Silogisme model $\mathrm{X}$

Jika tidak terjadi $q$ maka tidak terjadi $\mathrm{p}$ dan jika tidak terjadi $\mathrm{r}$ maka tidak terjadi q sehingga dapat disimpulkan jika terjadi p maka terjadi $r$.

k. Silogisme model XI

Jika tidak terjadi q maka tidak terjadi $\mathrm{p}$ dan jika tidak terjadi $\mathrm{r}$ maka tidak terjadi q sehingga dapat disimpulkan jika tidak terjadi $r$ maka tidak terjadi $\mathrm{p}$.

1. Silogisme model XII

Jika tidak terjadi $\mathrm{q}$ maka tidak terjadi $\mathrm{p}$ dan jika tidak terjadi $\mathrm{r}$ maka tidak terjadi q sehingga dapat disimpulkan jika terjadi $\mathrm{p}$ maka terjadi $\mathrm{r}$ atau jika tidak terjadi $\mathrm{r}$ maka tidak terjadi $\mathrm{p}$.

Pada model 3, 6, 9 dan 12 merupakan silogisme dengan menggunakan hukum indempoten yang menyatakan $\mathrm{p}$ atau/dan $\mathrm{p}$ maka sama halnya menyatakan p sehinga nilai kebenarannya ekuivalen. Oleh sebab itu pada kesimpulan ada dua kemungkinan yaitu impilkasi atau kontraposisi. 


\section{Aplikasi Silogisme dalam Pembelajaran Matematika}

Silogisme dapat aplikasikan dalam berbagai aspek aktifitas diantaranya perencanaan, pelaksanaan, evaluasi dan pembuatan laporan (Karso, 1999). Dalam pembelajaran matematika pastilah menggunakan silogisme, karena dasar pemikiran matematika adalah logika. Pembelajaran matematika di SD haruslah diawali dengan beberapa merupakan konsep dasar sederhana yang akan digunakan untuk menerima konsep dasar kompleks (Sobel dan Maletsky, 2002). Siswa SD akan lebih mudah merima konsep dasar sederhana terlebih dahulu dari pada harus menerima konsep dasar yang komplek. Hal tersebut dikarenakan pada pemikiran usia siswa SD masih bersifat konkret dan sederhana. Aplikasi dalam pembelajaran matematika sebagai berikut.

a. Silogisme model I

- Jika guru menjelaskan luas segitiga agar siswa dapat menghitung luas segitiga dan jika siswa dapat menghitung luas segitiga maka siswa dapat menghitung luas permukaan limas segitiga sehingga dapat disimpulkan jika guru menjelaskan luas segitiga maka siswa dapat menghitung luas permukaan limas segitiga;

- Jika 120 genap maka habis dibagi 20 dan jika 20 genap maka habis dibagi 2 sehingga dapat disimpulkan jika 120 genap maka habis dibagi 2.

b. Silogisme model I

- Jika guru menjelaskan luas segitiga agar siswa dapat menghitung luas segitiga dan jika siswa dapat menghitung luas segitiga maka siswa dapat menghitung luas permukaan limas segitiga sehingga dapat disimpulkan jika siswa tidak dapat menghitung luas permukaan limas segitiga maka guru tidak/belum menjelaskan luas segitiga;

- Jika 120 genap maka habis dibagi 20 dan jika 20 genap maka habis dibagi 2 sehingga dapat disimpulkan jika tidak habis dibagi 2 maka 120 ganjil.

c. Silogisme model II

- Jika guru menjelaskan luas segitiga agar siswa dapat menghitung luas segitiga dan jika siswa dapat menghitung luas segitiga maka siswa dapat menghitung luas permukaan limas segitiga sehingga dapat disimpulkan jika guru sudah menjelaskan luas segitiga maka siswa dapat menghitung luas permukaan limas segitiga atau siswa tidak dapat menghitung luas permukaan limas segitiga maka guru tidak/belum menjelaskan luas segitiga;

- Jika 120 genap maka habis dibagi 20 dan jika 20 genap maka habis dibagi 2 sehingga dapat disimpulkan jika 120 genap maka habis dibagi 2 atau jika tidak habis dibagi 2 maka 120 ganjil.

d. Silogisme model III

- Jika guru menjelaskan luas segitiga agar siswa dapat menghitung luas segitiga dan jika siswa tidak dapat menghitung luas permukaan limas segitiga maka siswa tidak/belum dapat menghitung luas segitiga sehingga dapat disimpulkan jika guru sudah menjelaskan luas segitiga maka siswa dapat menghitung luas permukaan limas segitiga; 
- Jika 120 genap maka habis dibagi 20 dan jika tidak habis dibagi 2 maka 20 ganjil sehingga dapat disimpulkan jika 120 genap maka habis dibagi 2.

e. Silogisme model IV

- Jika guru menjelaskan luas segitiga agar siswa dapat menghitung luas segitiga dan jika siswa tidak dapat menghitung luas permukaan limas segitiga maka siswa tidak/belum dapat menghitung luas segitiga sehingga dapat disimpulkan jika siswa tidak dapat menghitung luas permukaan limas segitiga maka guru tidak/belum menjelaskan luas segitiga;

- Jika 120 genap maka habis dibagi 20 dan jika tidak habis dibagi 2 maka 20 ganjil sehingga dapat disimpulkan jika tidak habis dibagi 2 maka 120 ganjil.

f. Silogisme model V

- Jika guru menjelaskan luas segitiga agar siswa dapat menghitung luas segitiga dan jika siswa tidak dapat menghitung luas permukaan limas segitiga maka siswa tidak/belum dapat menghitung luas segitiga sehingga dapat disimpulkan jika guru sudah menjelaskan luas segitiga maka siswa dapat menghitung luas permukaan limas segitiga atau siswa tidak dapat menghitung luas permukaan limas segitiga maka guru tidak/belum menjelaskan luas segitiga;

- Jika 120 genap maka habis dibagi 20 dan jika tidak habis dibagi 2 maka 20 ganjil sehingga dapat disimpulkan jika 120 genap maka habis dibagi 2 atau jika tidak habis dibagi 2 maka 120 genap.

g. Silogisme model VI

- Jika siswa tidak dapat menghitung luas segitiga maka guru tidak/ belum menjelaskan luas segitiga dan jika siswa dapat menghitung luas segitiga maka siswa dapat menghitung luas permukaan limas segitiga sehingga dapat disimpulkan jika guru sudah menjelaskan luas segitiga maka siswa dapat menghitung luas permukaan limas segitiga;

- Jika tidak habis dibagi 20 maka 120 ganjil dan jika 20 genap maka habis dibagi 2 sehingga dapat disimpulkan jika 120 genap maka habis dibagi 2.

h. Silogisme model VII

- Jika siswa tidak dapat menghitung luas segitiga maka guru tidak/ belum menjelaskan luas segitiga dan jika siswa dapat menghitung luas segitiga maka siswa dapat menghitung luas permukaan limas segitiga sehingga dapat disimpulkan siswa tidak dapat menghitung luas permukaan limas segitiga maka guru tidak/belum menjelaskan luas segitiga;

- Jika tidak habis dibagi 20 maka 120 ganjil dan jika 20 genap maka habis dibagi 2 sehingga dapat disimpulkan jika tidak habis dihabis 2 maka 120 genap.

i. Silogisme model VIII

- Jika siswa tidak dapat menghitung luas segitiga maka guru tidak/ belum menjelaskan luas segitiga dan siswa dapat menghitung luas segitiga jika maka siswa dapat menghitung luas permukaan limas segitiga sehingga dapat disimpulkan jika guru sudah menjelaskan luas segitiga maka siswa dapat menghitung luas permukaan limas segitiga atau siswa tidak dapat 
menghitung luas permukaan limas segitiga maka guru tidak/belum menjelaskan luas segitiga;

- Jika 120 ganjil maka tidak habis dibagi 20 dan jika 20 genap maka habis dibagi 2 sehingga dapat disimpulkan jika 120 genap maka habis dibagi 2 atau jika tidak habis dibagi 2 maka 120 ganjil.

j. Silogisme model IX

- Jika siswa tidak dapat menghitung luas segitiga maka guru tidak/ belum menjelaskan luas segitiga dan jika siswa tidak dapat menghitung luas permukaan limas segitiga maka siswa tidak dapat menghitung luas segitiga sehingga dapat disimpulkan jika guru sudah menjelaskan luas segitiga maka siswa dapat menghitung luas permukaan limas segitiga;

- Jika tidak habis dibagi 20 maka 120 ganjil dan jika tidak habis 2 maka 20 ganjil sehingga dapat disimpulkan jika 120 genap maka habis dibagi 2.

k. Silogisme model X

- Jika siswa tidak dapat menghitung luas segitiga maka guru tidak/ belum menjelaskan luas segitiga dan jika siswa tidak dapat menghitung luas permukaan limas segitiga maka siswa tidak dapat menghitung luas segitiga sehingga dapat disimpulkan jika siswa tidak dapat menghitung luas permukaan limas segitiga maka guru tidak/belum menjelaskan luas segitiga;

- Jika tidak habis dibagi 20 maka 120 ganjil dan jika tidak habis dibagi 2 maka tidak terjadi q sehingga dapat disimpulkan jika tidak terjadi $r$ maka tidak terjadi $\mathrm{p}$.

1. Silogisme model XI

- Jika siswa tidak dapat menghitung luas segitiga maka guru tidak/ belum menjelaskan luas segitiga dan jika siswa tidak dapat menghitung luas permukaan limas segitiga maka siswa tidak dapat menghitung luas segitiga sehingga dapat disimpulkan jika guru sudah menjelaskan luas segitiga maka siswa dapat menghitung luas permukaan limas segitiga atau siswa tidak dapat menghitung luas permukaan limas segitiga maka guru tidak/belum menjelaskan luas segitiga;

- Jika tidak habis dibagi 20 maka 120 ganjil dan jika tidak habis dibagi 2 maka 20 ganjil sehingga dapat disimpulkan jika 120 genap maka habis dibagi 2 atau jika tidak habis dibagi 2 maka 120 ganjil.

\section{Penutup}

Secara logis perencanaan pembelajaran mengunakan silogisme dapat menghindari ketidaksinaambungan tahap-tahap pembelajaran di SD. Dalam mengawali pembelajaran haruslah sesuai dengan perencanaan sehingga pada tahap akhir pembelajaran akan diperoleh hasil maksimal (Karim dan Widagdo, 2002). Berdasarkan uraian di atas maka pengambilan keputusan/kesimpulan dengan menggunakan silogisme: (1) pengambilan kesimpulan dengan cara lain haruslah mempertahankan bahwa cara lain tersebut merupakan sebuah tautology dan bukan kontradiksi; (2) model silogisme ada beberapa macam, maka oleh sebab itu dalam penggunaannya disesuaikan dengan premis-premisnya sehingga dapat disimpulkan dengan benar dan baik; (3) premis pada silogisme merupakan 
sebuah pernyataan majemuk implikasi dan kontraposisi implikasi yang mempunyai nilai kebenaran ekuivalen; dan (4) kesimpulan pada silogisme merupakan pernyataan tunggal sebagai alasan pada presmis awal yang diimplikasikan dengan pernyataan tunggal sebagai konklusi pada premis akhir, ataupun dengan kontraposisi. 


\section{DAFTAR RUJUKAN}

Karim, M. A., dan Widagdo, D. 2002. Materi Pokok PGSD 2401 / 3 SKS / Modul 1 - 9 Pendidikan Matematika II. Jakarta: Pusat Penerbitan Universitas Terbuka.

Karso. 1999. Materi Pokok PGSD 2303 / 3 SKS / Modul 1 - 9 Pendidikan Matematika I. Jakarta: Pusat Penerbitan Universitas Terbuka.

Lipschutz, S., dan Silaban, P. 1985. Teori Himpunan (Set Theory). Jakarta: Erlangga.

Munir, R. 2005. Matematika Diskrit. Bandung: Informatika.

Setiaji. 2008. Logika Informatika. Yogyakarta: Graha Ilmu.

Sobel, M. A., dan Maletsky, E. M2002. Mengajar Matematika: Sebuah Buku Sumber Alat Peraga, Aktivitas, dan Strategi untuk Guru Matematika SD, SMP, SMA. Jakarta: Erlangga.

Sukirman. 2001. Materi Pokok PGSD 2204 / 4SKS / Modul 1 - 6 Matematika. Jakarta: Pusat Penerbitan Universitas Terbuka.

Wall, E. 2010. Number Theory for Elementary School Teacher. New York: The City College of New York. 